\title{
JUER \\ Using Project-Based Learning in Improving Students' Critical Thinking Skills to Separate of Mixtures
}

\author{
Nurul Insani ${ }^{a, \star}$, Noor Fadiawati ${ }^{a, b}$, Ratu Betta Rudibyani ${ }^{a, b}$, M. Mahfudz Fauzi Syamsuri ${ }^{\mathrm{b}}$ \\ ${ }^{a}$ Magister of Natural Science Teacher Training, Faculty of Teacher Training and Education, University of \\ Lampung, Bandar Lampung, Indonesia \\ ${ }^{b}$ Department of Chemical Education, Faculty of Teacher Training and Education, University of \\ Lampung, Bandar Lampung, Indonesia
}

*Corresponding author: nurulinsani22@yahoo.co.id

\begin{abstract}
Nowadays the development of thinking skills has become the main focus in educational research. Standard of graduate competency mandate that graduates of schools to universities in Indonesia must have thinking skills. Related to this, the goal of this quasi-experimental study was to describe the effectivity of Project-Based Learning (PjBL) student worksheets to improve students' critical thinking skills (CTS) in the topic of mixtures separation. This study was carried out in the SMPN 1 Pugung by using the Non-Equivalent (Pretest-Posttest) Control Group Design. The effectivity of PjBL student worksheets measured based on the $n$-gain and the effect size values. Statistically, the $n$-gain value of the experimental class was higher than the control class. The effect size value was in medium categorized. These results indicated that the PjBL student worksheets were effective to improve students' CTS in the topic of mixtures separation.
\end{abstract}

Keywords: student worksheets, project-based learning, critical thinking skills, mixtures separation

\section{INTRODUCTION}

In the $21^{\text {st }}$ century, the development of thinking skills has become the main focus in educational research [1-6]. The thinking skills in this era became a basic principle to deal with the challenges of work and society [7]. It is because of there was competition in the global job market so that only qualified human resources would be winner $[8,9]$.

Thinking skills can be divided into two parts, namely simple thinking skills and higher-order thinking skills. According to Regulation of the Minister of Education and Culture of the Republic of Indonesia No. 20 in the 2016 year, the standard of graduate competency mandate that graduates from elementary till secondary schools in Indonesia must have thinking skills, such as thinking logically, analytically, systematically, critically, creatively, and collaboration. In additionally, students' higher-order thinking skills in Indonesia are still classified as very low. Result of the Organization for Economic Cooperation and Development's (OECD's) Program for International Student Assessment (PISA) has shown that in the 2009 Indonesia ranked 61 out of 65 participating countries, in 2012 ranked 64 out of 65 participating countries, and in 2015 ranked 69 out of 76 countries [10].

According to Presseisen, a person is said to be able to think about a higher-order if he has skills in problems solving, decisions making, critical thinking, and creative thinking [11]. Ennis said that critical thinking skills (CTS) are reasonable reflective thinking that focuses on deciding what to believe or do [12]. In other hands, results of the consensus conceptualization of critical thinking which held by 46 experts in the CTS defines that CTS is self-regulation in deciding which has goals that produce interpretations, analysis, evaluation, and inference as well as real, conceptualized, methodical, criteria or contextual considerations on which decisions are made [13].

Students' CTS will be trained and improved if students are challenged with real-world problems. One topic that is believed to be able to develop and improve students' CTS is the topic of mixtures separation. According to Regulation of the Minister of Education and Culture of the Republic of Indonesia No. 37 in 2018 year, secondary school students are expected to have the competence to do a separate of mixtures based on physical and chemical properties so that students can understand the characteristics of 
substances, as well as physical and chemical changes in substances that can be used for everyday life.

Project-based learning ( $\mathrm{PjBL}$ ) model is one of the suggested learning models to develop and improve students' CTS [14]. PjBL invites students to carry out activities such as observing, classifying, communicating, and forming students' scientific attitudes. Some researchers report that PjBL is effective in improving CTS and higher-order thinking skills to recycle waste cooking oil $[15,16]$, creative thinking skills to construct simple apparatus for experiment in laboratory [17], student learning outcomes [18,19], learning motivation, creativity, CTS, and cognitive abilities of students [20].

In this paper, we report the study which are used PjBL student worksheets. The student worksheets guide the students to solve the problems that appear in the project. Through this PjBL, the students can identify the problems with synthesis the essential questions, engage in designing the project to solve the problems, implementing and also evaluating the project. Therefore, it can improve students' CTS in the topic of mixtures separation.

\section{METHODS}

The quasi-experimental study was implemented in SMPN 1 Pugung by using the Non-Equivalent (Pretest-Posttest) Control Group Design. Samples in this study are students in the A and D-class of the 7th grade which is obtained by using purposive sampling technique. D-class used as the experimental class and A-class used as the control class.

TABLE 1. Design of Non-Equivalent (Pretest-Posttest) Control Group

\begin{tabular}{cccc}
\hline Group & Pretest & Treatment & Posttest \\
\hline Experimental & $\mathrm{O}$ & $\mathrm{X}$ & $\mathrm{O}$ \\
Control & $\mathrm{O}$ & $\mathrm{C}$ & $\mathrm{O}$ \\
\hline
\end{tabular}

Information: $\mathrm{O}$ is pre-/post-test, $\mathrm{X}$ is treatment in experimental class with $\mathrm{PJBL}$, and $\mathrm{C}$ is control class with conventional learning.

The effectivity of PjBL student worksheets measured based on the n-gain and the effect size values. The n-gain value is interpreted according to Hake's Standard [21].

$$
<\mathrm{g}>=\frac{\% \text { posttest score }-\% \text { pretest score }}{100-\% \text { pretest score }}
$$

TABLE 2. The n-gain criteria

\begin{tabular}{|c|c|}
\hline$<g\rangle$ & Pretest \\
\hline$\geq 0.7$ & high \\
\hline $\begin{aligned} 0.7 & <g \geq 0.3 \\
& <0.3\end{aligned}$ & $\begin{array}{l}\text { medium } \\
\text { low }\end{array}$ \\
\hline
\end{tabular}

In other hands, the effect size value is interpreted according to Cohen's Standard [22]. The hypothesis test is carried out by using t-test with SPSS version 25.

$$
\mathrm{d}=\frac{\mu_{\text {true }}-\mu_{\text {hyp }}}{\sigma}
$$

TABLE 3. The effect size criteria

\begin{tabular}{cc}
\hline$<\mathbf{g}>$ & Pretest \\
\hline $0.6-2.0$ & large \\
$0.3-0.5$ & medium \\
$0.0-0.2$ & small \\
\hline
\end{tabular}




\section{RESULT AND DISCUSSION}

The pretest and posttest score of CTS students in both classes are shown in Figure 1.

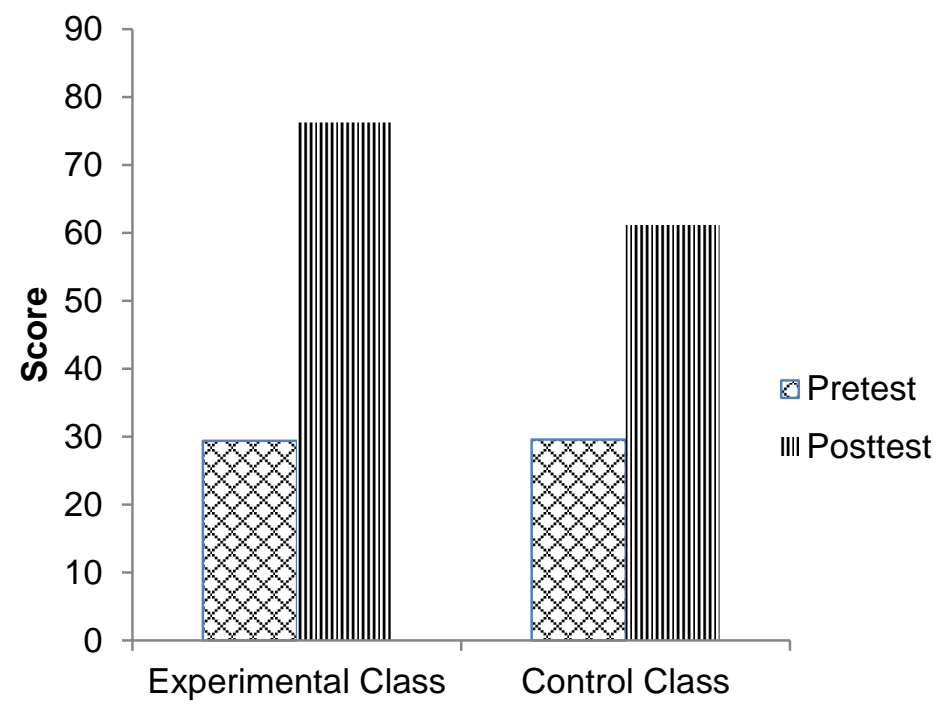

FIGURE 1. The pretest and posttest score of CTS students in the experimental and the control classes

The $n$-gain value of CTS students in both classes are shown in Figure 2.

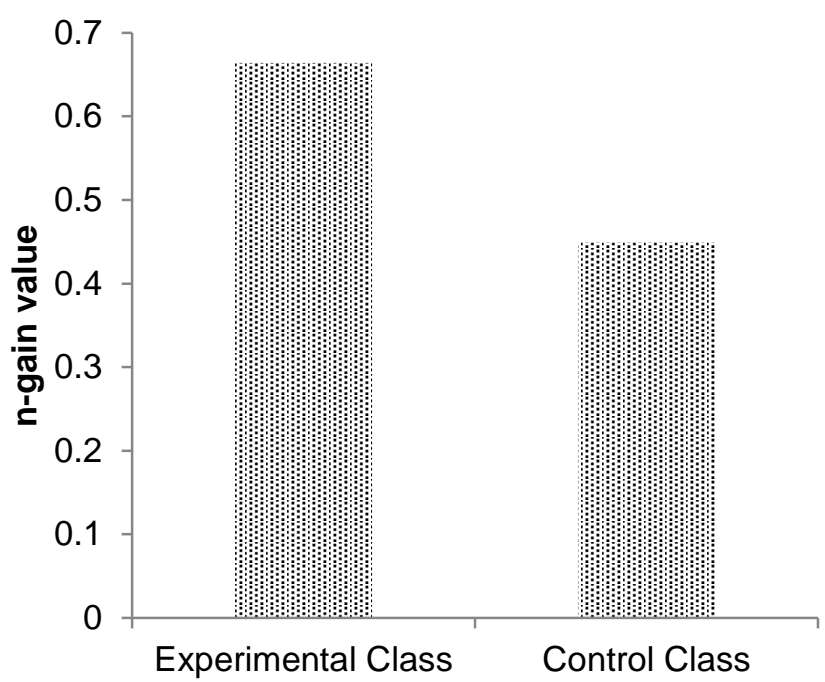

FIGURE 2. The n-gain value of CTS students in the experimental and the control classes

Result of the normality test for pretest score, posttest score, and n-gain value of CTS students was presented in Table 4.

TABLE 4. Result of the normality test

\begin{tabular}{cccccccc}
\hline \multirow{2}{*}{$\mathbf{N}$} & \multirow{2}{*}{ Item } & \multicolumn{4}{c}{ Experimental Class } & \multicolumn{3}{c}{ Control Class } \\
& & Pretest & Posttest & n-gain & Pretest & Posttest & n-gain \\
\hline 25 & Asymp.Sig.(2-tailed) & 0.497 & 0.635 & 0.729 & 0.503 & 0.392 & 0.509 \\
\hline
\end{tabular}


Result of the homogeneity test for pretest score, posttest score, and n-gain value of CTS students were presented in Table 5.

TABLE 5. Result of the homogeneity test

\begin{tabular}{ccccc}
\hline Data & Levene Statistic & df1 & df2 & sig. \\
\hline Pretest & 0.058 & 1 & 48 & 0.810 \\
Posttest & 0.457 & 1 & 48 & 0.502 \\
n-gain & 1.539 & 1 & 48 & 0.221 \\
\hline
\end{tabular}

Result of the t-test of CTS students was presented in Table 6.

TABLE 6. Result of the t-test CTS students

\begin{tabular}{ccccc}
\hline Class & n-gain & \multicolumn{3}{c}{ t-test for equality of means } \\
$\mathbf{x} \pm \mathbf{S D}$ & Sig. (2-tailed) & Mean Difference & Std. Error Difference \\
\hline $\begin{array}{c}\text { Experimental } \\
\text { Control }\end{array}$ & $0.6704 \pm 0.11710$ & 0.000 & 0.2340 & 0.40474 \\
\hline
\end{tabular}

Based on Figure 1, the pretest score of CTS students in the experimental and the control classes were 29.4 and 29.6, respectively. Statistically, students both in the experimental and the control classes were considered to have the same initial CTS. In other hands, the posttest score of CTS students in the experimental and the control classes were 76.3 and 61.2, respectively. Statistically, CTS students in the experimental class was higher than the control class.

Based on Figure 2, the n-gain value of CTS students in the experimental and the control classes were 0.664 and 0.449 , respectively. According to Hake's Standard, both classes in medium categorized. However, CTS students in the experimental class was higher than the control class statistically. In other hands, from the effect size test obtained a result of 0.4. According to Cohen's Standard, the effect size value in medium categorized. Therefore, both results, $n$-gain and effect size values, indicated that the PjBL student worksheets were effective to improve students' CTS in the topic of mixtures separation.

\section{Step 1. Identify the Problems with Synthesis the Essential Questions}

In this step, students to deal the problem related to water pollution which was presented in a discourse. Students were asked to identify the problems with synthesis the essential questions. Initially, majority of students make questions that were less relevant to the problem presented. In order to assist the students, the teacher provides scaffolding. Generally, relevant questions can be synthesized by students.

\section{Step 2. Engage in Designing the Project to Solve the Problems}

According to guideline in the student worksheets, students in their group were given tasks to synthesis the aims of the project, the importance of the project, a detailed list of the apparatus and the materials, procedures' description of the project conduction, timeline and deadline the project. Before designing the project, students were asked to identify variables and look for information related to water pollution and how efforts have been made by other people to overcome these problems.

\section{Step 3. Implementing and Monitoring the Project}

According to design, timeline, and deadline, students implementing project outside of the class. During the project, students consulted with the teacher regularly because implementing design is not one-time process. During the project too, students were asked to report progress of the project.

\section{Step 4. Evaluating the Project}

After the project has finished, students were asked to present result of the project. During presentation, students from other group respond to related the project. With learning like this, students' CTS based on the Ennis [23] framework can improve adequately. 


\section{CONCLUSION}

The n-gain value of CTS students in experimental class is higher than the control class statistically. The effect size value was in medium categorized. These are indicated that the PjBL student worksheets were effective to improve students' CTS in the topic of mixtures separation. During the project, $\mathrm{PjBL}$ carry out activities such as observing, classifying, communicating, and forming students' scientific attitudes.

\section{REFERENCES}

1. K.J. Topping and A. Bryce, EP, 24, 5, 595-621, (2004).

2. R. Fisher, Thinking Skills. Learning to Teach in the Primary School Series 1 Edited by J. Arthur, T. Grainger, and D. Wray,, (Routledge, United Kingdom, 2006), pp. 374-386.

3. L.A. Burke and J.M. Williams,. ECDC, 179, 7, 949-968, (2009).

4. D. Colcott, B. Russell, and H. Skouteris, TD, 1, 17-27, (2009).

5. R.N. Beyers, JSET, 19, 5, 447-455, (2010).

6. C. Aubrey, K. Ghent, and E. Kanira, IJEYE, 20, 4, 332-348, (2012).

7. D. Moseley, J. Elliott, M. Gregson, M., and S. Higgins, BERJ, 31, 3, 367-390, (2005).

8. A. Benešová, M. Hirman, F. Steiner, and J. Tupa, Analysis of Education Requirements for Electronics Manufacturing within Concept Industry 4.0. International Spring Seminar on Electronics Technology (ISSE), (Pilsen, Czech Republic, 2018), pp 1-5.

9. M. Baygin, H. Yetis, M.Karaköse, and E. Akin,. An Effect Analysis of Industry 4.0 to Higher Education, Proceeding of 15th International Conference on Information Technology Based Higher Education and Training (ITHET). (Istanbul, Turkey, 2016), pp. 8-10.

10. Organization for Economic Cooperation and Development. Programme for International Student Assessment. [Online]: http://www.oecd.org/pisa/ (January, 2018).

11. A.L. Costa and Pressceisen, Developing Minds: A Resource Book for Teaching Thingking, (Virginia ASCD, Alexandria, 1985).

12. R.H. Ennis, TP, 14, 1, 5-24, (1991).

13. C.P. Dwyer, M.J. Hogan, and I. Stewart. JTSC, 12, 43-52, (2014)

14. C. Diawati, Liliasari, A. Setiabudi, and Buchari. AIP, 1, 1, 1-6. (2017).

15. N.D. Jamaludin, "Pengaruh Pembelajaran Berbasis Proyek Terhadap Kemampuan Berpikir Kritis dan Sikap Ilmiah pada Materi Tumbuhan Biji", Bachelor. Thesis, STAIN Kudus Jawa Tengah, 2017.

16. I.A.K. Sastrika, I.W. Sadia, and Muderawan. JPPII, 3, 1, 1-10, (2013).

17. C. Diawati, Liliasari, A. Setiabudi, and Buchari. JCE, 95, 3, 468-475 (2018)

18. H.E. Fini, F. Awadallah, M.M. Parast, and T. Abu-Lebdeh, EJEE, 43, 3, 473-488, (2017).

19. R. Mardiani, "Pengaruh Model Pembelajaran Berbasis Proyek (PjBL) terhadap Hasil Belajar Siswa pada Konsep Impuls dan Momentum", Bachelor. Thesis, Universitas Islam Negeri Syarif Hidayatullah, (2017).

20. D. Insyasiska, S. Zubaidah and H. Susilo, JPB. 7, 1, 9-21, (2015).

21. R.R. Hake, AJP, 66, 1, 64-74. (1998).

22. E.W. Minium and B.M.K.G. Bear, Statistical Reasioning In Psychology And Education. (United State of America, 1993)

23. R. H. Ennis, Critical Thinking (University of Illinois, New York, 1981) 